Aleksa Radonjić, $\mathbf{P h D}{ }^{*}$

Original scientific paper

UDC: 366.5(4-672EU)

doi: $10.5937 /$ spzo-19828

\title{
BEHAVIORAL APPROACH TO UNFAIR TERMS AND CONDITIONS IN EU CONSUMER LAW
}

\author{
Abstract
}

Rational choice theory is still at the hearth of EU consumer law. In this paper I consider how this theory reflects on the unfair terms control mechanism set by the Unfair Contract Terms Directive. I identify most pressing problems in the field of unfair contract terms using the findings of behavioral psychology and behavioral economics. In search for possible solutions to these problems I will consult the relevant literature. Therefore, method I use here is a theoretical application of the behavioral findings. In conclusion I will assess which solutions are feasible and most desirable in a short term period, and which are the most effective but demand certain investments and time to become fully functional. Finally, I will conclude that behavioral approach to the issue of unfair contract terms and conditions is an important addition to the policing of unfair terms and conditions which could lead to the raise of overall quality of terms and conditions which is a significant step beyond the control of unfairness.

Keywords: consumer law, unfair contract terms, behavioral approach.

\section{Introduction}

The corner stone of EU consumer law are information duties. ${ }^{1}$ For example, the Consumer Rights Directive prescribes that the traders must disclose twenty different information to a consumer before concluding a distance or an off premises contract. ${ }^{2}$ Such an approach goes hand in hand with the assumption that consumers are perfectly rational, and that the only problem they face on the market is the information asymmetry, which

\footnotetext{
* Teaching fellow at the Faculty of Law, Union University in Belgrade, e-mail:aleksa.radonjic@pravnifakultet.rs.

${ }^{1}$ H. A. Luth, Behavioral Economics in Consumer Policy: The Economic Analysis of Standard Terms in Consumer Contracts Revisited (PhD thesis), Erasmus University Rotterdam, Rotterdam 2010, 214, https:// repub.eurnl/pub/19572/Proefschrift-Hanneke-A.-Luth.pdf, last visited November 14, 2018.

${ }^{2}$ See Directive 2011/83/EU, OJ L 304/64, Article 6.
} 
can be remedied by the mandatory pre-contractual duties to inform. ${ }^{3}$ This assumption is a fruit of rational choice theory, which assumes that human beings are, when provided with sufficient information, capable of rationally choosing among many options the one that is maximizing their welfare. ${ }^{4}$

However, the reality and the research in behavioral psychology prove the opposite. First, while we may lack information, we also lack attention. ${ }^{5}$ We have innate limits as to the amount of information we are able to process at a time. ${ }^{6}$ I would add that we also lack time to make the best of the information we gather since we all have to perform many tasks every day. Therefore, even when provided with comprehensive information consumers may fail to make the right decision because of the information overload. ${ }^{7}$ Furthermore, we are not as rational as one may think. Human beings are susceptible to the influence of emotion, and motivation when making decisions. ${ }^{8}$ And make no mistake: even experts are prone to various biases. ${ }^{9}$ As Anne-Lise Sibony simply puts it: "Behavioral studies show that we are all "idiots"..." ${ }^{\prime 10}$ For all the above stated reasons human behavior deviates from the behavioral pattern expected from a rational welfaremaximizing person, and it does so regularly and predictably. ${ }^{11}$ Confronted with too many choices they have to make within a little time and burdened by innate cognitive limitations, people rely on "cognitive rules of thumb, known as heuristics" which lead to incorrect evaluations and judgments. ${ }^{12}$ For example, people often choose the instant gratification even if in the end that leads to higher costs than had they made a different decision. ${ }^{13}$ Another example is egocentric bias which results in over-optimism making people

\footnotetext{
${ }^{3}$ A-L. Sibony, "Can EU Consumer Law Benefit from Behavioural Insights? An Analysis of the Unfair Practices Directive", European Review of Private Law 6/2014, 901-903.

${ }^{4}$ K. Mathis, A. D. Steffen, "From Rational Choice to Behavioral Economics: Theoretical Foundations, Empirical Findings and Legal Implications", in: European Perspectives on Behavioral Law and Economics (ed. Klaus Mathis), Cham 2015, 31.

${ }^{5}$ A-L. Sibony, 903.

${ }^{6}$ See e.g. G. A. Miller, “The Magical Number Seven, Plus or Minus Two: Some Limits on Our Capacity to Process Information", The Psychological Review 2/1956.

${ }^{7}$ M. G. Faure, H. A. Luth, "Behavioural Economics in Unfair Contract Terms Cautions and Considerations", Journal of Consumer Policy 3/2011, 344.

${ }^{8}$ A. Tor, "The Methodology of the Behavioral Analysis of Law", Haifa Law Review 4/2008, https://scholarship.law.nd.edu/law faculty scholarship/836, last visited September 26, 2018, 242.

9 "Research also shows that financial professionals give better ratings to investments with aesthetically pleasing annual reports than to those with less attractive reports that contain exactly the same data." see R.H. Thaler, W. Tucker, "Smarter Information, Smarter Consumers", Harvard Business Review 1/2013, https:// hbr.org/2013/01/smarter-information-smarter-consumers, last visited November 22, 2018.

${ }^{10}$ A-L. Sibony, 905.

${ }^{11}$ A. Tor, 242-243.

${ }^{12}$ K. Mathis, A. D. Steffen, 37.

${ }^{13}$ A-L. Sibony, 907 fn. 19.
} 
to overestimate the likelihood of positive outcomes, and underestimate the probability of negative outcomes. ${ }^{14}$ Also providing too much information and too many choices makes impossible for consumers to competently assess the information and consequently makes them stick to defaults without questioning them or looking for better solutions. ${ }^{15}$ This is just to state a few examples.

A research conducted for European Commission also showed that consumers generally do not read the terms and conditions of contracts they sign. ${ }^{16}$ Even when they do, or when they suffer from the unfair terms and conditions, they quite often do not take any action to bring the matter before the court or other authority. ${ }^{17}$ This made me think about the efficiency of the Unfair Contract Terms Directive (UCTD). ${ }^{18}$ One could say that there is no reason to worry since the UCTD prescribes that the unfair terms shall not be binding weather or not consumers read them. ${ }^{19}$ Also, UCTD obliges the Member States to provide effective means of protection against unfair contract terms which also means allowing third parties such as consumer organizations or public authorities to take actions against unfair T\&Cs. ${ }^{20}$ Next to the unfairness test ${ }^{21}$, UCTD, furthermore, provides for a non-exhaustive list of terms and conditions that may be deemed unfair. ${ }^{22}$ Some Member States, like the Netherlands, introduced black and gray lists, the former representing the list of terms that are always deemed to be unfair, and the latter containing terms that are refutably assumed to be unfair ${ }^{23}$ making the matter much easier for the ones who are to assess the fairness of the terms. Therefore, if consumers

\footnotetext{
${ }^{14}$ K. Mathis, A. D. Steffen, 40.

${ }^{15}$ M. Engel, J. Stark, "Buttons, Boxes, Ticks, and Trust: On the Narrow Limits of Consumer Choice”, in: European Perspectives on Behavioral Law and Economics (ed. Klaus Mathis), Cham 2015, 113.

${ }^{16}$ European Commission, Study on consumer's attitudes towards Terms and Conditions (T\&Cs), Final report, 2016 - Study, https://ec.europa.eu/info/sites/info/files/terms_and_conditions_final_report_en.pdf, last visited November 12, 2018, 5. Note that this study showed that consumers do not read T\&Cs when concluding online contracts, but even if one goes to e.g. telecommunications company to conclude a contract on the spot, does one really reads the $\mathrm{T} \& \mathrm{Cs}$ before he/she signs the contract?

${ }^{17}$ Ibid., 10

${ }^{18}$ Council Directive 93/13/EEC of 5 April 1993 on unfair terms in consumer contracts - UCTD, OJL 95/29.

${ }^{19}$ UCTD, Article $6(1)$.

${ }^{20}$ UCTD, Article 7 (2): “... shall include provisions whereby persons or organizations, having a legitimate interest under national law in protecting consumers, may take action according to the national law concerned before the courts or before competent administrative bodies for a decision as to whether contractual terms drawn up for general use are unfair, so that they can apply appropriate and effective means to prevent the continued use of such terms."

${ }^{21}$ UCTD, Article 3 (1).

${ }^{22}$ UCTD, Article 3 (3) and Annex to the Directive.

${ }^{23}$ A. Radonjić, 'Unfair Contract Terms and SMEs in BW and Draft CC of Serbia", Strani pravni život 4/2017, 242.
} 
do not read T\&Cs, these will still be invalidated by the court or other authority, and if consumers do not initiate these proceedings there are others authorized to do that.

Still, this empowerment of other actors beside consumers with the right to initiate a procedure for the assessment of the fairness of the terms and conditions is said not to have yielded desired results. ${ }^{24}$ This implies that there is a lot to be done to solve the problem of unfair contract terms in consumer contracts, and that some changes to the mechanism established by the UCTD are warranted. These changes regard both the regulatory and the enforcement policies. In this paper I will focus on the regulatory aspect. A starting point in this paper is that these changes should be informed by findings of behavioral research, and I will try to look for concrete solutions.

I will first present what I find to be the key challenges to the existing system of control of T\&Cs. Then I will present the possible solutions offered in the literature. Finally, I will draw some conclusions. The method I will use in this paper is theoretical application of behavioral findings to the legal issue ${ }^{25}$ I chose. I opted for this method because, for the time being, I do not have training and knowledge to perform relevant behavioral research on my own.

\section{The most pressing problems in the realm of unfair terms and conditions}

\subsection{Consumers do not read $T \& C s$}

As Ben-Sahar simply puts it: "Real people don't read standard form contracts. ${ }^{26}$ This has been also confirmed in research. ${ }^{27}$ There are various reasons for this, and usually they are combined. People lack time. ${ }^{28}$ They also overestimate their knowledge of their rights as consumers. ${ }^{29}$ T\&Cs are hard to understand due to complicated legal language and their length, and even simplified ones are not always easy to comprehend. ${ }^{30}$ Furthermore, consumer's ability to foresee potential harms arising out ${ }^{24}$ H. A. Luth, 232.

${ }^{25}$ A. Tor, 275.

${ }^{26}$ O. Ben-Sahar, "The Myth of the Opportunity to Read in Contract Law", European Review of Contract Law (ERCL) 1/2009, 2.

${ }^{27}$ See e.g. the Study, 9, or M. G. Faure, H. A. Luth, 349.

${ }^{28}$ O. Ben-Sahar, 14.

${ }^{29}$ Study, 10.

${ }^{30}$ O. Ben-Sahar, 13. 
of usage of a product or a service is limited hence limiting the ability to understand the importance of particular T\&Cs. ${ }^{31}$ Consumers would also have to know the default rules of contract law in order to assess whether the T\&Cs deviate from those default rules, and in whose favor, ${ }^{32}$ which they usually do not know. Finally, consumers lack the incentive to read regardless the previous constraints because there is nothing they can do about the T\&Cs; the scenario in which a consumer renegotiates the T\&Cs with a big company is not a realistic one. ${ }^{33}$

\subsection{Egocentric bias}

As explained in the introduction to this paper, egocentric bias results in over-optimism and overconfidence leading to underestimating the possibility of something bad happening to a person, and to overestimating probability of positive outcomes. ${ }^{34}$ The research showed that consumers often overestimate their future self-control which makes them to accept e.g. fitness -club or mobile phone subscription plans which are not the most beneficial to them. ${ }^{35}$ The same bias could make them to accept unfair $\mathrm{T} \& \mathrm{Cs}$ in those contracts even when they read them. It is fair to assume for instance that a person would accept a clause in those subscription plans that obligates them to pay a lot of money as a penalty in case of premature rescission of the contract. Since one is confident that they will stick to the subscription plan, one would not attach much importance to this clause even if it is unfair because they are confident that they would not rescind the contract. So over-optimism is relevant in situations where consumers judge the probability of occurrence of negative outcomes, especially outcomes which occurrence in part depends on consumer's behavior. ${ }^{36}$ Therefore, it is particularly important to take this bias into the account when assessing the $T \& C$ s which attach some kind of penalty to an outcome that is at least partly dependable of consumer's behavior. By assessing I do not just mean the assessment by the court, but also the assessment which terms and conditions should be prohibited or assumed to be unfair, or labeled as such.

\footnotetext{
${ }^{31}$ Ibid., 14.

${ }^{32}$ Ibid.

${ }^{33}$ O. Ben-Sahar, 2.

${ }^{34}$ See n. 14.

${ }^{35}$ H. A. Luth, 63.

${ }^{36}$ A. Tor, 278 .
} 


\subsection{Status quo bias and the endowment effect}

Status quo bias means that people generally prefer their present state instead of an alternative one. ${ }^{37}$ This makes a person to stick to defaults, and when terms provided by the trader are perceived as defaults it is likely that consumers will stick to them. ${ }^{38}$ Consumers are likely to hold on to even inefficient T\&Cs if the effects of status quo bias outweigh the possible benefits of rescinding the contract. ${ }^{39}$ This is closely connected to lose aversion which makes people give greater significance to loses, than to equivalent gains, which leads to inability to realize potential gains..$^{40}$ Add to this the information overload and inability to process and assess all the information available it is clear consumers will be very reluctant to switch to another trader or to different T\&Cs.

Endowment effect is closely related to the status quo bias, and it manifests itself as a person's tendency to attach greater value to objects he or she owns than to those they do not own. ${ }^{41}$ In the context of unfair T\&Cs the long free trial periods could create a sense of ownership and make consumers attach the greater value to the good on trial than they would actually value $\mathrm{it}^{42}$ and consequently lead them to disregard or undervalue the unfavorable terms and conditions of a contract for purchase of that good.

\subsection{Framing effect}

Framing effect denotes the influence of the presentation of information or choices to perception of that information or those choices which then influences the decision making. The now famous "Asian disease" problem demonstrates how people can choose one alternative over another, but reject the alternative with the same outcome only differently described, and vice versa. ${ }^{43}$ This made me think that presentation of T\&Cs can also play an important role, and that unfavorable or unfair T\&Cs can be formulated in such a way that they are perceived as fair and benign.

Another aspect of framing is the fact that choices are referencedependent, which means that we assess alternatives as gains or losses against

\footnotetext{
${ }^{37}$ Ibid., 264.

${ }^{38}$ H. A. Luth, 64.

${ }^{39}$ A. Tor, 268, for this matter see also n. 15.

${ }^{40}$ K. Mathis, A. D. Steffen, 40-41.

${ }^{41}$ M. G. Faure, H. A. Luth, 344.

${ }^{42}$ H. A. Luth, 65.

${ }^{43}$ For a detailed description of the experiment see A. Tor, 260-261.
} 
some reference point. ${ }^{44}$ This means that one and the same outcome could be favored or undesired depending of the reference point we acquired. I will discuss this particular aspect of framing effect down the road when I will search for solutions to behavioral challenges to current policy on unfair terms.

\section{Possible solutions}

\subsection{Increase the readership of $T \& C s$}

As it was mentioned before one of the problems consumers encounter, is information overload. Add to this problem the complexity of T\&Cs and one can hardly blame a person giving up on reading them at all. So, in order to increase the readership of T\&Cs reducing the number of information provided, and simplifying them and taking care of the form these are provided in should be considered. The research commissioned by European Commission showed that simplifying the language of T\&Cs increased the readership by $16 \%{ }^{45}$ The same research showed that indicating that reading the T\&Cs will take only 5 minutes increased the readership by little more than $10 \%{ }^{46}$

Furthermore, the complexity of the content of information is not the only problem; it is also the form in which information is presented. ${ }^{47}$ Thus, suggestions as to the letters sizes used for different parts of the texts, summaries, shorter sentences etc. can be found. ${ }^{48}$ There are recommendations that longer texts, such T\&Cs typically are, ought to be user-friendly structured by using headings, highlighted keywords, or that some information should be presented in the form of FAQs etc. ${ }^{49}$ Also T\&Cs should be related to real-life situations, supported by examples and put in the context so that consumers better understand them. ${ }^{50}$

However, all these strategies to increase the number of consumers who read T\&Cs are welcome but generally of limited success. As to the percentages stated above, if we take that studies show that only $4-5 \%$ of consumers read the $\mathrm{T} \& \mathrm{Cs}^{51}$ then an increase in 10 or $16 \%$ is not significant success in absolute numbers. Furthermore, the European Commission's

\footnotetext{
${ }^{4}$ Ibid., 261.

45 Study, 12.

${ }^{46}$ Ibid, 10-11.

48 Ibid., 25.

49 Ibid., 27.

50 Ibid., 29.

${ }^{51}$ M. G. Faure, H. A. Luth, 349.
}

${ }^{47}$ N. Helberger, "Form Matters: Informing Consumers Effectively", Amsterdam Law School Legal Studies Research Paper No. 2013-71, 4, http://ssrn.com/abstract=2354988, last visited November 12, 2018. 
study showed that one and the same contract term was seen as unfair before it was simplified and as fair after it was put in simpler language. ${ }^{52}$ This shows that simplifying the terms does not necessarily lead to better understanding of those terms, and that substantive control and outlawing certain terms and conditions is still needed.

When it comes to better visual presentation of $\mathrm{T} \& \mathrm{Cs}$ and their form it seems fair to demand from businesses to use at least part of their resources they invest into marketing techniques to convince consumers to buy their services and products into more user-friendly display of T\&Cs. However, if we want to translate that duty into legal norm it is hard to go much beyond what we already have..$^{53}$ So model forms of T\&Cs would make a good addition to the general call for simple and comprehensible language. I will deal with this idea in more detail a bit later.

At this point I wish to conclude this part that all the strategies aiming at raising the readership of T\&Cs are limited, as I have shown, because in the absolute numbers the readership, generally, will not be very high. These strategies, however, could be quite useful in those industries where consumers typically read the contracts. For instance it is reported that $72 \%$ of consumers read car rental contracts, and that $73 \%$ of consumers read mortgage contracts. ${ }^{54}$ Once again, even in these industries high readership does not guarantee high understanding of the terms and clauses, and here as in other fields policymakers must go beyond the readership-increase strategies.

\subsection{Labeling and rating}

Since it is established that consumers usually will not read the contracts for many reasons, and that even if they do it is likely they will not be able to understand them well enough to make a sound decision, the alternative is to signal the consumers in a simple and catchy way that T\&Cs of a contract they wish to conclude are fair or unfair. The question is how?

One way would be labeling. Similar to food labels the most relevant contract terms to consumers would have to be displayed on products. ${ }^{55}$ The point is to summarize essential information in easily readable format displayed with or on products making that information available prior to purchase. ${ }^{56}$ It is also important that these information focus on negative

${ }^{52}$ Study, 12.

${ }^{53}$ UCTD prescribes that T\&Cs have to be drafted in plain and intelligible language, see. Art. 4 and 5.

${ }_{55}^{54}$ M. G. Faure, H. A. Luth, 349.

55 H. A. Luth, 246.

${ }^{56}$ O. Ben-Sahar, 25. 
aspects or unfavorable T\&Ss just as food labels put the spotlight on fat, sugar, certain fatty acids or other unhealthy ingredients. ${ }^{57}$ As Ben-Sahar said: "The reason why in the first place we are concerned with unreadable terms is the existence of negative terms, and thus these are the terms that would prominently appear on the label." 58

Labeling, however, has flaws. First, it does not guarantee that consumers would understand the implications of displayed terms. They still could make wrong assessments of those terms as they usually do particularly when assessing the risks..$^{59}$ Second, many terms are excluded from scrutiny. ${ }^{60}$ It is possible to identify terms that regulate issues that are most relevant to consumers or that consumers usually complain about, ${ }^{61}$ and then prescribe mandatory labeling of those terms. Nevertheless, this leaves room to traders to hide other detrimental terms and conditions among those not on the label.

The other way of signaling the quality of T\&Cs to consumers would be rating. It means collecting data about $\mathrm{T} \& \mathrm{Cs}$ and giving a contract a particular mark or score depending on the quality of those terms. ${ }^{62}$ The simplest methodology is developed by Florencia Marotta-Wurgler where she assigns a value of +1 to every term which favors a buyer more than a default rule set by the law, -1 for every term that offers a buyer less than what is offered by default rule set by the law, and 0 for a term that is as beneficial to a buyer as default rule set by the law. ${ }^{63}$ Since she was testing the end-user license agreements (EULAs), all with the same number of T\&Cs she determined the overall score of the contract as the sum of all the values. ${ }^{64}$

One objection to this method could be that contracts do not necessarily have the same number of terms as is the case with EULAs that were tested by Marotta-Wurgler, so the aggregate score could be misleading. But this can be overcome using the simple proportion where the score would be displayed in percentages. Furthermore, I would add to this very visible information that the score means that contract offers $\mathrm{n}$ more than the law or $\mathrm{n}$ less than the law in order to set the default

\footnotetext{
${ }^{57}$ O. Ben-Sahar, 26.

${ }^{58}$ Ibid.

${ }^{59}$ H. A. Luth, 246.

${ }^{60}$ Ibid., 247.

${ }^{61}$ For example, the Study showed that most frequent problems consumers have are related to delivery and return of goods, the Study, 10.

62 H. A. Luth, 245.

${ }^{63}$ F. Marotta-Wurgler, "Are "Pay Now, Terms Later" Contracts Worse for Buyers? Evidence from Software License Agreements", The Journal of Legal Studies 2/2009, 312.

${ }^{64}$ Ibid.
} 
rules of the law as a reference point for a consumer. The consumer does not even have to know the default rule. They are informed that T\&Cs offer them something more or less than it is offered by the law, and it is a clear enough signal to them that by these terms they win or lose something. This way the reference-dependence bias can be used in favor of consumers, not against them.

There is another objection to this method that comes to my mind. I am not sure if we should ascribe the same value to all the T\&Cs. Namely, if certain T\&Cs govern the issues that are unlikely to arise, it is questionable to what extent they should influence the total score of the contract. It could happen that some contracts get better or worse scores on account of less important terms and conditions. Still, even with this flaw, I consider this method useful. It does not single out unfair T\&Cs, but all the ones which offer less than default rules set by the law, which means that it potentially can influence the overall enhancement of T\&Cs, not just eradication of unfair ones. Which is more, it is simple, and objective (more objective than customer experience for sure), and it's easy to check the credibility of the assessor (if they lied or not about the score).

That last remark leads to the question of who would do the rating. Would that be a public authority, a consumer organization(s), or a third private party. Given the simplicity of the method described it should not incur significant costs so rating could be entrusted to a consumer organization. This could be a good solution given that the research showed the quality cues provided by consumer organizations are the most trusted by consumers. ${ }^{65}$ The precondition to the rating is that traders make their T\&Cs available to the public in an easily accessible format.

\subsection{Smart disclosure}

If consumers would be able to get deciphered information about products and services they buy and T\&Cs under which they buy those, and get the information on time, they would be able to assess if those goods or services suit their needs and to compare offers available on the market. To make this happen, we can use technology for processing the ever-growing amount of data humans generate every day. In order for technology to process this data in a most effective manner, it has to be in a machine readable format. ${ }^{66}$ This idea was promoted by Thaler

\footnotetext{
65 Study, 11.

${ }^{66}$ R.H. Thaler, W. Tucker.
} 
and Sunstein as Record, Evaluate, and Compare Alternative Prices (RECAP) ${ }^{67}$ In the USA a version of this idea was adopted under a catchy name Smart Disclosure which means: "timely release of complex information and data in standardized, machine-readable formats in ways that enable consumers to make informed decisions."

There are examples of services developed by private parties that use the available data to help us make informed decisions. Compare engines make good example. We can use them to compare the prices of hotel rooms, to check if products we want meet our environmental or social standards etc. ${ }^{69}$ Also, applications and services that would use personal data of product and service users could be very helpful in suggesting them the appropriate subscription plans or making them aware of their use patterns, or average use patterns ${ }^{70}$ to override the effect of egocentric biases. Informing consumers about the average use patterns could also set new, more realistic defaults or reference points thus using these biases in favor of consumers. Information about average use patterns would be particularly beneficial if a consumer is to subscribe for a service for the first time so there are no data about their habits and usage so the personalized subscription plan cannot be suggested. But in order to make it possible to assess the quality of T\&Cs for these services, they have to be, not only accessible online in real time, but machine readable. ${ }^{71}$ And there is also the issue of personal data and its usage. There are already in place, in different sectors, duties to provide information in standardized machine readable format that for example improve decision making regarding investment. ${ }^{72}$ It is not unimaginable to make mandatory to disclose T\&Cs in standardized machine readable language which would then open the door for services similar to compare engines which would compare the T\&Cs under which services and goods are offered. This way, consumers would be able to choose more favorable T\&Cs among many (without actually reading them) on the market inciting competition between traders regarding T\&Cs. And as for the usage of the data about our behavior, well we already disclose them just for the sake of being able to post on Facebook or Twitter. Why not disclose them for the sake of better terms of service we give money for?

\footnotetext{
${ }^{67} \mathrm{Ibid}$.

${ }^{68} \mathrm{Ibid}$.

${ }^{69} \mathrm{Ibid}$.

${ }^{70}$ See more on this in N. Helberger, 32-34

${ }^{71}$ R.H. Thaler, W. Tucker.

${ }^{72}$ Ibid.
} 
The challenge on the path to make the disclosure of T\&Cs smart is to distribute the burden of translation of T\&Cs into machine readable formats justly. It should not impose significant costs upon private sector. ${ }^{73}$ Also, in my view another challenge is not to oversimplify the law, and not to prevent the creativity and innovation in contracts if the costs of translation into machine readable formats show to be significant, or the capacity of this technology shows to be insufficient to follow the developments of new notions and ideas which may arise in contract law. Of course, this is not the reason to discard smart disclosure, but to search for solutions to counter its possible flaws.

This technology could be coupled with rating making the latter automatic and more efficient. However, I have a doubt regarding both methods and their combination. Namely, I find it hard to imagine that the technology behind these services could be so sophisticated to apply fairness test in form of a general rule like it is prescribed by UCTD. There are too many variables and too many nuances in the language that can cause the term to be unfair that I just do not think machine can cope with in the proper way. Then again, this is not a very strong argument since I am not an expert for this technology. It is just my skepticism, and only the time will show if it was justified or not. Furthermore, no one says that machines would have to replace the judges in interpreting the law. If they succeed to inform consumers in an easily understandable way who offers better T\&Cs for the same product or service, that would enable consumers to shop for better T\&Cs. This could provoke competition among traders to offer better T\&Cs which in turn could lead, as a side effect, to rare use of unfair T\&Cs by the traders.

\subsection{Pre-approval of $T \& C s$}

Pre-approving T\&Cs by an administrative body or a private interest group is another idea how to cope with unfair T\&Cs. ${ }^{74}$ The competent body would check if the T\&Cs which trader wishes to use complied with all legal requirements, and if they did the approval would be issued. ${ }^{75}$ The version of this solution is used in Israel where companies may submit their T\&Cs for pre-approval to Standard Term Tribunal. ${ }^{76}$ If the Tribunal

\footnotetext{
${ }^{73} \mathrm{Ibid}$.

${ }^{74}$ H. A. Luth, 258.

${ }^{75}$ Ibid., 258-259.

${ }^{76}$ Ibid., 259.
} 
determines that T\&Cs do not contain "any "unduly disadvantages" or onerous terms" then it approves them. ${ }^{77}$ A business which acquired the approval by the Tribunal is then allowed to place the seal of approval on the contract or make it visible to consumers in other ways. ${ }^{78}$

This approach could be coupled with rating mechanism mentioned earlier so the seal issued by the competent authority could also signal if T\&Cs offer more to consumers than the minimum required by the law. This could be the answer to the critique that pre-approval does not necessary guarantee high quality of contracts if the minimum level set by the law is not very high either. ${ }^{79}$

\subsection{Negotiated model forms of $T \& C s$}

Negotiated model forms of T\&Cs would be standard model contracts resulting from the negotiations between business and consumer organizations, thus enabling consumer representatives to take part in drafting of T\&Cs. ${ }^{80}$ This mechanism is already in use in many European countries (Scandinavian countries, the Netherlands, France etc.). ${ }^{81}$ The experience shows that this approach is less successful where the signed agreements on model contracts are binding only to the signatory parties and at the local level. ${ }^{82}$ Therefore, it seems more effective if the once agreed model is binding countrywide and to all the market participants.

The argued advantages of this regulatory strategy are many. First, it is said that these negotiations, since they are carried out by those who are most affected by the T\&Cs and mostly familiar with their own preferences regarding them, should provide most efficient contract forms.$^{83}$ Second, it provides legal certainty for businesses because there is low or no chance of legal disputes should they adhere to negotiated model forms.$^{84}$ It would also reduce the costs of drafting T\&Cs which is particularly beneficial to small and medium sized enterprises (SMEs). ${ }^{85}$ It is also a good forum to make model forms in consumer-friendly language, and to employ the knowledge of marketing experts for the benefit of consumers. This way the

\footnotetext{
${ }^{77} \mathrm{Ibid}$.

${ }^{78}$ Ibid.

${ }^{79}$ Ibid., 260.

${ }^{80}$ H. A. Luth, 263.

${ }^{81}$ Ibid., 263-264.

${ }^{82}$ Ibid., 265.

${ }^{83}$ Ibid., 266.

${ }^{84}$ Ibid., 267.

${ }^{85}$ Ibid., 266.
} 
impossibility to make more precise legal norm regarding intelligibility and comprehensiveness of the language of T\&Cs would be bridged. Not only the content, but the form too would be negotiated. Finally, the fact that a business is adhering to a negotiated standard contract could be interpreted as a sign of quality of T\&Cs offered. ${ }^{86}$ This approach could then signal the consumers which T\&Cs have certain level of quality even if consumers do not read them, and it would provide more comprehensible language of $\mathrm{T} \& C$ s for those consumers who actually would read the T\&Cs.

The possible downside of this regulatory strategy is inadequate consumer representation. Namely, it is fair to expect that consumer organizations would not be able to negotiate on equal footing with business organizations because former have less funds and expertise, weaker bargaining power, and represent potentially very diverse interests. ${ }^{87}$ Therefore, before introducing this model of regulation of T\&Cs, the practices from the countries where this model showed to be successful should be investigated and checked if they are applicable in the domestic setting. Also, funding and training to consumer representative organizations should be provided should the policymakers opt for this model. ${ }^{88}$

\section{Conclusion}

As it is shown in this paper, the main problem of the mechanism established by UCTD is that consumers do not read T\&Cs for various reasons many of which are objective and justified. Even if consumers would read the T\&Cs it is questionable if they would be able to understand them correctly, and if they would be able to assess and interpret them properly due to various cognitive biases. The other problem is reluctance of consumers to initiate proceedings against unfair T\&Cs. This lack of action is partly caused by the lack of readership because one has to read the T\&Cs to know if they should act upon it. Even the authorization of third parties to initiate the proceedings instead of consumers seems not to have given the desired results. The whole mechanism of UCTD rests on the action by the consumer or other party against the T\&Cs because otherwise the competent authority will not be able to assess the fairness of the T\&Cs. This does not mean that the mechanism set by UCTD should be discarded. It only means that it should be complemented.

\footnotetext{
${ }^{86}$ Ibid., 267-268.

${ }^{87}$ Ibid., 270.

${ }^{88}$ Ibid., 271.
} 
Therefore, the persistence of unfair and unfavorable T\&Cs should be cured in other ways complementary to the regime set by UCTD. These other ways should be behaviorally informed. Since the research showed that readership-increase-strategies do not raise the number of readers significantly, and that raising the number of readers and simplifying the T\&Cs does not guarantee better understanding of them, the main aim should not be to increase the readership. The aim should be to raise the awareness of consumers about the quality of T\&Cs without actually reading them. The most promising approach to this end in my view is smart disclosure despite all my skepticism. However, it seems that it takes time and money to implement it. Negotiated-model-formsapproach seems like a good mechanism, but the one that demands specific preconditions to be met in order to be efficient. One of those preconditions is well trained and financially empowered consumer NGO sector which is also something to be accomplished on the long run at least in poorer Member States. What I believe is possible to be done in a short term is the implementation of some simple method of rating like Wurgler's is by consumer organizations or public authorities especially if coupled with pre-approval mechanism. The latter seems simple, cheap and effective enough while the scene is being prepared for the smart disclosure.

Finally, it should be noted that judicial review of T\&Cs or preapproving them by a public authority are fit procedures for the assessment of the fairness of T\&Cs. Other mechanisms suggested here are not proper tools or forums for such assessments. However, the latter are designed to signal if a consumer should look for a better choice regardless of the unfairness. This is an important addition to the policing of unfair T\&Cs. This could lead to the raise of overall quality of T\&Cs which is a significant step beyond the control of unfairness. Therefore, behavioral approach to the issue of unfair T\&Cs could set consumers on a more equal footing with businesses.

\section{References}

Ben-Sahar, O., "The Myth of the Opportunity to Read in Contract Law", European Review of Contract Law (ERCL) 1/2009, 1-28.

Engel, M., Stark, J., "Buttons, Boxes, Ticks, and Trust: On the Narrow Limits of Consumer Choice", in: European Perspectives on Behavioral Law and Economics (ed. Klaus Mathis), Cham 2015, 107-123. 
Faure, M. G., Luth, H. A., "Behavioural Economics in Unfair Contract Terms Cautions and Considerations", Journal of Consumer Policy 3/2011, 337-358.

Marotta-Wurgler, F., "Are "Pay Now, Terms Later" Contracts Worse for Buyers? Evidence from Software License Agreements", The Journal of Legal Studies 2/2009, 309-343.

Mathis, K., Steffen, A. D., "From Rational Choice to Behavioral Economics: Theoretical Foundations, Empirical Findings and Legal Implications", in: European Perspectives on Behavioral Law and Economics (ed. Klaus Mathis), Cham 2015, 31-48.

Miller, G. A., "The Magical Number Seven, Plus or Minus Two: Some Limits on Our Capacity to Process Information", The Psychological Review 2/1956, 81-97.

Radonjić, A., "Unfair Contract Terms and SMEs in BW and Draft CC of Serbia", Strani pravni život 4/2017, 239-251.

Sibony, A-L., "Can EU Consumer Law Benefit from Behavioural Insights? An Analysis of the Unfair Practices Directive", European Review of Private Law 6/2014, 901-941.

\section{Legal sources}

Directive 2011/83/EU of the European Parliament and of Council of 25 October 2011, OJ L304/64.

Council Directive 93/13/EEC of 5 April 1993, OJ L95/29.

\section{Website references}

European Commission, Study on consumer's attitudes towards Terms and Conditions (T\&Cs), Final report, 2016, https://ec.europa.eu/ info/sites/info/files/terms_and_conditions_final_report_en.pdf, last visited November 12, 2018.

Helberger, N., "Form Matters: Informing Consumers Effectively", Amsterdam Law School Legal Studies Research Paper No. 2013-71, http:// ssrn.com/abstract $=2354988$, last visited November 12, 2018.

Luth, H. A., Behavioral Economics in Consumer Policy: The Economic Analysis of Standard Terms in Consumer Contracts Revisited (PhD thesis), Erasmus University Rotterdam, Rotterdam 2010, https://repub.eur.nl/pub/19572/Proefschrift-Hanneke-A.-Luth. $p d f$, last visited November 14, 2018. 
Thaler, R. H., Tucker, W., "Smarter Information, Smarter Consumers", Harvard Business Review 1/2013, https://hbr.org/2013/01/smarter-information-smarter-consumers, last visited November 22, 2018.

Tor, A., "The Methodology of the Behavioral Analysis of Law", Haifa Law Review 4/2008, https://scholarship.law.nd.edu/law_faculty_ scholarship/836, last visited September 26, 2018, 237-327.

\section{Dr Aleksa Radonjić}

Asistent, Pravni fakultet Univerziteta UNION u Beogradu

\section{BIHEVIORALNI PRISTUP NEPOŠTENIM UGOVORNIM KALUZULAMA U POTROŠAČKOM PRAVU EU}

\section{Rezime}

U radu se polazi od toga da je osnova potrošačkog prava EU u velikoj meri i dalje teorija racionalnog izbora. Ova teorija podrazumeva da su potrošači racionalni i da kada imaju dovoljno informacija donose odluke koje maksimizuju njihovu dobrobit. Bihevioralna istraživanja $u$ psihologiji i ekonomiji opovrgavaju ovu teoriju i pokazuju da se iz različitih objektivnih razloga potrošači ne ponašaju u skladu sa njom. Kada je reč o nepoštenim ugovornim klauzalama i sistemu kontrole koji je uspostavljen Direktivom EU o nepoštenim ugovornim klauzulama pokazalo se da mehanizmi koje ona predviđa nisu dovoljni kako bi se potrošači zaštitili od takvih ugovornih klauzula. Sistem koji je ovim propisom uspostavljen u velikoj meri zavisi od toga da li potrošači čitaju ugovore, ako ih čitaju da li su u stanju da ih razumeju i tumače na ispravan način i da li pokreću sudske ili druge postupke kada su pogođeni nepoštenim ugovornim klauzulama. Istraživanja pokazuju da oni ne čitaju ugovore, čak i kada ih čitaju često nisu u stanju da razumeju ugovorne odredbe i da se retko upuštaju u sudske ili druge postupke. U literaturi se tvrdi da čak ni ovlašćivanje organizacija potrošača da pokreću postupke zbog upotrebe nepoštenih ugovornih odredbi nije dalo odgovarajuće rezultate. Opisano ponašanje potrošača i njihova nesposobnost da procene značaj pojedinih ugovornih odredbi se može objasniti različitim kognitivnim ograničenjima koja su imanentna ljudima bez obzira na stepen obrazovanja i obazrivost. 
Zbog toga se u radu nabrajaju najrelevantniji bihevioralni problemi $\mathrm{u}$ vezi s nepoštenim ugovornim klauzulama. Zatim se razmatraju i ocenjuju konkretna rešenja na koja se naišlo u literaturi. Metod koji se koristi jeste teoretska primena rezultata bihevioralnih istraživanja. $\mathrm{Na}$ kraju se izvodi zaključak da bihevioralni pristup zaštiti potrošača od nepoštenih ugovornih klauzula predstavlja važan dodatak postojećem sistemu kontrole ovih ugovornih odredbi; da predložene mere ne mogu zameniti sudsko odlučivanje o nepoštenosti ugovornih odredbi, ali da mogu dovesti do podizanja ukupnog kvaliteta ugovornih klauzula koje trgovci nude potrošačima, što je i više od kontrole nepoštenosti tih ugovornih klauzula.

Ključne reči: potrošačko pravo, nepoštene odredbe potrošačkih ugovora, bihevioralni pristup. 